\title{
Coopted! Mission Drift in a Social Venture Engaged in a Cross- sectoral Partnership
}

\author{
Barinaga, Ester
}

\author{
Document Version \\ Accepted author manuscript \\ Published in: \\ Voluntas \\ DOI: \\ $10.1007 / \mathrm{s} 11266-018-0019-6$ \\ Publication date: \\ 2020 \\ License \\ Unspecified
}

Citation for published version (APA):

Barinaga, E. (2020). Coopted! Mission Drift in a Social Venture Engaged in a Cross-sectoral Partnership. Voluntas, 31(2), 437-449. https://doi.org/10.1007/s11266-018-0019-6

Link to publication in CBS Research Portal

\section{General rights}

Copyright and moral rights for the publications made accessible in the public portal are retained by the authors and/or other copyright owners and it is a condition of accessing publications that users recognise and abide by the legal requirements associated with these rights.

\section{Take down policy}

If you believe that this document breaches copyright please contact us (research.lib@cbs.dk) providing details, and we will remove access to the work immediately and investigate your claim.

Download date: 26. Apr. 2023






\section{Coopted! Mission Drift in a Social Venture Engaged in a Cross- sectoral Partnership}

\section{Ester Barinaga}

Journal article (Accepted version*)

\section{Please cite this article as:}

Barinaga, E. (२०२०). Coopted! Mission Drift in a Social Venture Engaged in a Cross-sectoral Partnership. Voluntas, 31(2), 437-449. https://doi.org/10.1007/s11266-018-0019-6

This is a post-peer-review, pre-copyedit version of an article published in Voluntas. The final authenticated version is available online at:

Q0l: https://doi.org/10.1007/s11266-018-0019-6

* This version of the article has been accepted for publication and undergone full peer review but has not been through the copyediting, typesetting, pagination and proofreading process, which may lead to differences between this version and the publisher's final version AKA Version of Record. 


\title{
Coopted!
}

\section{Mission drift in a social venture}

\section{engaged in a cross-sectoral partnership}

This is the pre-published version. For the final version, see: Barinaga, E. 2019. "Coopted! Mission-drift in a social venture engaged in a cross-sectoral partnership." VOLUNTAS: International Journal of Voluntary and Nonprofit Organizations.

\begin{abstract}
Social entrepreneurship research highlights the collaborative nature of social entrepreneurial efforts. Further, acknowledging the embeddedness of social ventures in the wider socio-economic and cultural context, the literature stresses the need to move our analysis from the micro-level of intraorganizational practices to the meso-level of inter-organizational dynamics. To answer to these calls, the article engages Fligstein's and McAdam's theory of Strategic Action Fields (SAF) to investigate the dynamics of the interorganizational collaborative work of social ventures. Empirical material comes from the efforts of a social venture to scale up to a new city through developing a cross-sectoral collaboration with the city administration. Findings indicate the risk of mission-drift that weaker partners in SAFs run when collaborating with incumbent actors. In this doing, the study illustrates how a meso-level analysis can further our understanding of social entrepreneurial ventures in particular, and cross-sectoral partnerships in general.
\end{abstract}

Keywords: social venture, cross-sectoral partnership, Strategic Action Field, institutional order, collaboration 
"I'm going to give you a memory blank" says the tall and coloured young neighbour in a threatening tone. To my "tough, hey?" he answers, "do you think that I don't beat women?" A few minutes later, that same young man, together with a few others from the gang, are throwing stones onto Frida Kahlo Mural Art Centre's large windows, breaking one of them. It is a sunny day in the beginning of June 2012 and Förorten i Centrum (henceforth FiC), the social entrepreneurial initiative running Frida Kahlo, has been trying to get established in Seved (Malmö, Sweden) for the previous three months.

$\mathrm{FiC}$ is a social entrepreneurial venture using community-arts to work in the vulnerable and stigmatised suburbs of Sweden's cities. Started in Stockholm in 2010, in 2012 it set to scale up to the Sweden's Southern city of Malmö. As part of these efforts, FiC entered a collaboration with the city administration: The City of Malmö agreed to support FiC economically and administratively asking the social venture to open a community centre in what later showed up to be the city's most dangerous street corner. From March 2012, when FiC opened the Mural Art Centre, the organisation shared the corner made by Rasmus Street and Sofia Lane with a gang of young men who engaged in drug-dealing in broad day light. Unsurprisingly, the gang did not like to share the street corner with the communityarts social venture. That is, the threats and violence the organisation's employees were experiencing were more than simply sign of spiralling violence in Seved (Malmö). Direct violence was the immediate, most visible aspect of the more complex problem the organisation was confronted with: The difference in the institutional logics followed by the collaborating partners resulted in divergent framings of the social challenge in Seved. Coopted by the institutional logic of City Management into addressing a social problem for which it did not have the resources nor the knowledge and which drifted it away from its original mission (for two similar cases, see Milbourne and Cushman 2013). In this sense, the case can be seen as a micro-cosmos of state-citizen sector relationships (Milbourne and Murray 2011).

Taking FiC's efforts to expand into a new city as starting point, the article discusses the potential risky life of social ventures engaging in partnerships with the public sector. It uses Fligstein's and McAdam's (2012) theory of fields to delineate the strategic action field in which the partners work and to elicit the varied stakes and differing institutional logics guiding the actors involved in Seved's conflict as well as in the cross-sectoral partnership. Under this approach, a social venture's mission-drift arises as the result of the cooptation of the social venture - the weaker challenger, dependent on public city authorities for access to key resources - by city management - the dominant incumbent in the field. The first contribution of this article is thus to contextualise an organisation's mission-drift within the larger Strategic Action Field in which it acts, an analytical move that requires - and this is a second contribution - of a reconceptualisation of an organisation's context.

In a first step, the article turns to the literature on social entrepreneurship. This literature highlights the collaborative nature of the work of citizen initiatives, pointing out the need to look the processes through which these organisations build and maintain collaborative relationships. Further, acknowledging the embeddedness of these initiatives in a wider socio-economic and cultural context, the literature stresses the need to move our analysis from the micro-level of intra-organizational practices to the meso-level of inter-organizational dynamics. The article then argues that Fligstein's and McAdam's particular synthesis of organizational studies and social movement theory is well suited to attend to the embeddedness of the collaborative work of social entrepreneurial ventures. Finally, and this is the third contribution of the article, the study illustrates how such a meso-level analysis can further our understanding of the dynamics of social entrepreneurial ventures' collaborative work in particular, and of cross-sectoral partnerships in general. 


\section{Social Entrepreneurship: Organising for Social Change}

Although relatively young, social entrepreneurship has already become a vibrant field of research. Yet, as it is common in many a nascent research field, that of social entrepreneurship is not only troubled by disagreement on the definition of its phenomenon of interest (Aygören 2014; Dacin et al. 2011) and on the demarcation of its boundaries (Austin et al. 2006; Caroli et al. 2018; Trivedi and Stokols 2011). It is also troubled by a search for theoretical concepts and intellectual tools that can help understand the phenomenon in a comprehensive manner and bring coherence to the field (Curtis 2008; Dacin et al. 2010; Fayolle and Matlay 2009; Swedberg 2009).

The search for a theoretical framework and for a common definition notwithstanding, researchers do concur in pointing at social entrepreneurship's social heart (Barinaga 2012). Variously referred to as driven by 'social mission' (Nicholls 2008), creating 'social value' (Dacin et al. 2011), challenging the 'status quo' (Light 2009), or catalyzing 'positive social change' (Bacq and Janssen 2011), practitioners and students of social entrepreneurship acknowledge the need to shift attention from the economic to the social dimensions of 'entrepreneuring' (Calás et al. 2009; Daskalaki et al. 2015). This calls for theoretical frameworks that acknowledge the political mileage of social entrepreneurship (Barinaga 2013) and that can elicit the institutional and social aspects of entrepreneurial processes of organising for social change (Johansson et al. 2015; Mair and Marti 2006; Swedberg 2006).

There is a second point of agreement in the field: A growing awareness of the collaborative nature of the work needed for organising social innovation and entrepreneurship processes (Voorberg et al. 2015) in what is at times referred to as "citizen sector" (Drayton 2002; see also Douglas 2015). While an individualist focus on the entrepreneur still permeates mainstream research, a growing number of studies highlight the collective character of social ventures (Montgomery et al. 2012; Dacin et al. 2011), recognising, in particular, the central role of partnerships for opportunity recognition (Henry 2015), the co-creation of value (Austin and Seitanidi 2012), and gaining legitimacy (Sud et al. 2009). Some have gone as far as to suggest that social entrepreneurship is defined by its efforts to bricolage and build partnerships across sectors (Kickul et al. 2009). Yet, while recognising that social entrepreneurial agency is a collective endeavour, studies are also indicating the risk of mission-drift social ventures incur when partnering with incumbent actors (Cornforth 2014; Ebrahim et al. 2014). This has led many a scholar to call for studies that focus on the strategies and practices used by these initiatives to bring about and manage collaboration (Di Domenico et al. 2010; Sonnino and Griggs-Trevarthen 2013).

Third, studies of social entrepreneurship point to the relevance of the local, social and historical contexts in which social ventures work (Dacin et al. 2011; Newth and Woods 2014; Tapsell and Woods 2010; Smith and Stevens 2010). This is a particular area of concern, as the few empirical studies on this type of ventures tend to ignore the ways in which the contexts they are embedded in influence the recognition of opportunities (Newth and Woods 2014), the pool of resources (Vermeulen et al. 2016), the courses of action (Tapsell and Woods 2010) and the relationship to target groups (Seelos et al. 2011; Smith and Stevens 2010). This calls for a theoretical framework that allows us to balance an analysis of intra- and inter-organizational relations with analysis of larger social dynamics (Dacin et al. 2011).

As a corollary, and this is a fourth direction research is pointing out to, an interest in social entrepreneurship calls for theories that combine a focus on agency with one on larger institutional fields (Kalantaridis 2014; Battilana et al. 2009); it calls for analysis that elicit the dynamic relationship between organizational action at the micro-level and institutional frameworks at the macro-level (Dacin et al. 2011); it calls for concepts that allow us to account for the structures limiting action while 
nonetheless acknowledge the role of individuals and organisations in catalysing social change (Barinaga 2012; Curtis 2008). In an effort to account for the dynamic relation between agency and structure in social entrepreneurial efforts, scholars have looked into institutional theory's preference for stability while developing the notions of institutional entrepreneurship (Tracey et al. 2011; Dacin et al. 2010; Battilana et al. 2009) and institutional plurality (Mair et al. 2015) to be able to account for change. Others have explored the potential of combining institutional with social capital theories (Easter and Dato-On 2015); Schumpeter's entrepreneurial agency with Tarde’s social theory (Palmås 2012); as well as organization theory with entrepreneurship studies (Townsend and Hart 2008). Whatever the form of these theoretical incursions, that is, the challenge put forward by social entrepreneurship scholarship is to recognise structure and stability while nonetheless being able to account for agency and change.

Following the four directions indicated above, the article suggests using Fligstein and McAdam's general theory of fields for the analysis of the dynamics of a collaboration between a newly founded social venture and incumbent institutional actors. It does so because in its synthesis of new institutional theory in organizational studies and social movement theory, Fligstein and McAdam's notion of 'Strategic Action Field' bridges the gap between entrepreneurial agency and institutional embeddedness. In this doing, the theory of fields allows for a focus on collaborative practices as well as on the tensions between actors guided by different institutional logics. It is in these tensions that we will be able to recognise the political dimension of a cross-sectoral partnership between a social venture and a local public agency.

\section{'Strategic Action Fields' in the study of social entrepreneurship}

Interested on how institutions change, Fligstein and McAdam worked agency notions common in organization studies and social movement theory with structure notions common in institutional analysis. The result is a notion that addresses attention away from the micro-level of actions and away from the macro-level of institutions, to put the focus of attention onto the meso-level of 'strategic action fields'.

Strategic action field is the meso-level social order in which action takes place, and thus becomes the fundamental unit in the analysis of collective action. It is at the level of strategic action fields that we can observe how "actors interact with knowledge of one another under a set of common understandings about the purposes of the field, the relationships in the field (including who has power and why), and the field's rules" (Fligstein and McAdam 2010:3, emphasis is mine). This means that the boundaries of strategic action fields are determined by the situation or social problem that moves shifting sets of actors to define issues of concern, interact, collaborate, or compete (ibid.:4). This approach is parallel to those cross-sectoral partnerships that put the meta-problem or social issue as the main reason to partner (Selsky and Parker 2005). Accordingly, when analysing institutional change and collective action, the student of strategic action fields needs to look for stakeholders to the social issue, not for stakeholders to given organizations. This is, as it were, as much a theoretical demarcation as a piece of methodological advice.

A key distinction is due here, that between strategic action field and institutional order (or institutional sector, institutional environment, even institutional field). While 'institutional order' implies consensus in the logic of action endorsed by actors in the institutional field, 'strategic action field' (SAF) implies consensus on the social issue to be addressed by the actors, which is not to say that actors see the problem alike nor that they act towards it in similar fashion. Institutional orders are organised around a 'taken for granted' reality, actors perceive along the same logic. SAFs, by contrast, are organised around 
social meta-problems, actors contending about the nature of the problem. It is the potential for conflict among actors in SAFs, their struggles for definition of the problem, and their adjustment to each others' actions, that allows Fligstein and McAdam to account for the possibility of change (Fligstein and McAdam 2012).

The above distinction is of particular relevance to the study of social ventures engaged in a public partnership. The social issue sets the terms of the partnership while also delineating the SAF. This, however, does not mean that the partners can be seen as acting from within the same institutional order. Rather, while the social venture may be acting from the citizen sector, framing the social issue along community lines, the local public organization may guide its actions along the institutional logic proper of local government. That is, the cross-sectoral partnership conjures up a SAF yet the partners may remain distant in the institutional orders from which they partner (and act).

It is here that the notion of framing is key to the theory of fields. Taken from social movement theory (Benford and Snow 2000), Fligstein and McAdam engage it to distinguish the way actors approach the SAF, interpret each others' actions, and shape their own actions. In a sense, frames relate to 'logics of action'. These often follow the lines set by the institutional order from which each partner acts and implements the partnership. The concept of framing (or meaning-making) bridges the gap between what individuals do in the SAF and the institutional logics guiding their efforts; it allows us to move between agency and structure, between the micro- and the macro-level.

So far, a theory of fields tells us that actors (individual or collective) in a SAF act according to frames indicated by their institutional orders. This leaves little room for agency. Fligstein's and McAdam's next move re-introduces it: social skill. An actor's capacity to fashion its agency depends not only on the actor's position in the SAF and embeddedness in a given institutional order (and thus access to material, social, and cultural resources), but also on its social skills. Social skill is the ability to engage in an interactive process, jockey between frames, shape collective identities, create political coalitions, and define collaborative lines of action. SAFs are complex webs of relations, and actors' social skills are key to navigate those relations and induce collective action. For the social venture engaged in a crosssectoral partnership, social skill is the ability to manage the interface between various institutional orders (Reay and Hinings 2009).

To synthesise Fligstein's and McAdam's theoretical framework, and to outline the conceptual tools I will be using to understand a cross-sectoral partnership between a nascent social venture and a local state organization, let me list the elements of particular relevance:

- SAFs are situationally defined. In cross-sectoral partnerships enacted for solving a social challenge, the situation defining the SAF is made by the social issue partners are engaged in.

- Collective actors, such as the non-profit organization or the city authority, bring the frames and respond to the struggles of their own institutional environments. This accounts for a degree of stability in the way actors fashion their actions.

- Agency, and with it, change is reintroduced through actors' social skills. Their ability to build a sense of shared interests and interdependence is pivotal for organising collaboration.

With these conceptual elements in place, let me now turn our attention to the events that occurred in the Malmö Office of FiC during 2012. 


\section{FiC: A case study and a methodological approach}

FiC was founded in Stockholm in 2010, with the explicit mission to raise the voices of residents in the stigmatised suburbs of Swedish cities - "to let those that are talked about in the public debate take power over their own story". Through the collective production of large murals in public spaces, residents are organised and given a platform to raise up their voices and, in this way, nuance the defamed prevalent image of the stigmatised suburbs and their residents. By visualising in major outdoor walls alternative stories of the suburbs, FiC aims to counter territorial stigmatisation (Wacquant 2007). From its origins in 2010 till the summer of 2012, the organisation had successfully carried eight community murals in Sweden's capital alone. As a result, in the spring of 2012, FiC was granted funding to further scale up to Sweden's southern city of Malmö.

To prepare for the eventual expansion, I started meeting with various private, non-profit, and state organisations in Malmö already in the spring of 2011.1 The events here described come from the minutes from these meetings, as well as from my fieldwork notes from participating in them. Fieldnotes also come from active participation (Spradley 1980) in the meetings Karin Larssen ${ }^{2}-$ Executive $^{2}$ Manager of the Malmö Office of FiC from February 2012 - and I continued to have as we went about negotiating collaborations with diverse city actors, searching for additional funding, hiring and training staff for the Malmö Office, mobilising residents and building relations with local associations and resident groups. Finally, fieldnotes come from the weekly meetings Karin Larssen and I held as we discussed FiC's subsequent work. All together, some 43 meetings. Further empirical material comes from emails exchanged between partners, planning documents developed by the various partners and interviews with residents. In all, the study lasted from February 2011 to December 2012.

The varied nature of the qualitative material thus generated helped ensure the strength of the analytical findings, especially since the multiple sources of evidence converged. Such methodological pluralism helps the researcher to avoid the potential bias introduced by her active participation in the field, while generating a richer and more sophisticated understanding of the phenomenon studied (Brewer and Hunter 1989; Polkinghorne 1983).

Analysis of the empirical material proceeded in four stages. First, I wrote a detailed description of the events that occurred in Malmö during the spring of 2012 including the actors involved as well as their various actions and reactions. This description took the form of a teaching case (Quinn 1980, cited in Eisenhardt 1989). Further, I prepared interview and meeting transcripts and organised information in tables that identified actors as well as particular interactions. In a second step, I proceeded to analyse the material thus prepared along Geertz's three primary questions: who they think they are, what they think they are doing, and to what end they think they are doing it (Geertz 2000). This process allowed the unique framing guiding each actor to emerge. In a third step, I set to compare across actors' framings. Given the purpose of the study - to investigate the dynamics of a collaboration between a nascent social venture and incumbent institutional actors -, the first comparative dimension was how each collaborating partner framed the conflict in Seved. The author looked for those places and instances in which stakeholders justified the tactics they suggested and argued for the practices they implemented. A second comparative dimension was how stakeholders framed relations with each other

\footnotetext{
I This course of action is in line with recent research highlighting that co-created social innovations are mostly initiated by non-governmental actors (Nemec et al. 2017).

2 Except for myself, and to respect the integrity and confidentiality of the persons involved in the events here described, their names have been anonymised.
} 
as well as with other actors in the SAF. Discussions concerning selection of the target of their efforts became central here. This comparison developed into the table included in the findings section of this article. In a fourth and final step, the author reported the results of this analysis to the partner in the cross-sectoral collaboration. A meeting was held with representatives for the city administration, who confirmed and added nuance to the interpretation. Given that the author is the founder and chair of the social venture which is one of the partners of the collaboration studied, this meeting also allowed me to discuss potential bias in the analysis of data. Further sharing the analysis with research colleagues as well as fellow workers in the social venture was of particular relevance to avoid bias.

\section{Methodological approach}

For the purpose of this article, however, FiC will not only be used as an empirical case from which to learn the various challenges faced by social ventures involved in public partnerships. Since the article follows the social venture that I founded and continue to chair, $\mathrm{FiC}$ will also be the expression of a methodological approach to the study of entrepreneurial processes, that of entrepreneuring as method.

Appalled by the lack of agreement on even a working definition of entrepreneurship, in 1988, William Gartner suggested that a more productive approach in entrepreneurship research may come from shifting the focus of attention from 'Who is the entrepreneur?' to 'How does an organization come into existence?'. If, as he argued, entrepreneurship is "the process by which new organisations come into existence" (Gartner 1989:57), then, studies should be based on fieldwork of "entrepreneurs in the process of creating organisations" (Ibid.:63). Sarasvathy and Venkataraman (2011) take this shift of focus from individual traits to behavioural aspects of entrepreneuring a step further, and argue that entrepreneurship itself is "a method of thought and action" that, just as the scientific method, can be learnt and taught. Put differently, entrepreneurship scholars are suggesting the learning-by-doing logic that they see in entrepreneurial endeavours could also be applied to the very study of entrepreneurship. That is, entrepreneuring as a research method.

In this line, a number of scholars are starting to advocate for the use of auto-ethnography in entrepreneurship studies, ethnographies written by the entrepreneurs themselves (Johanisson 2011; Gartner 2016). Other scholars, in an effort to elicit the social and political dimensions of entrepreneurial processes, are calling for interventionist methods in research on entrepreneurship in general and social entrepreneurship in particular (Steyaert 2011). Interventionist research approaches, also referred to as action research or engaged scholarship (Van de Ven 2007), it is argued, are not only aware of the performative character of its methods; they also engage in the very construction of the reality they so study (Barinaga 2017; Gibson-Graham and Roelvink 2013).

Methodologically, this article is part of this emergent trend towards interventionist methods in entrepreneurship research. It follows the efforts, by my colleagues and me, to bring a collaboration into existence. In this doing, the article is able to elicit the frames brought by the collaborating partners, to follow actors' accommodations to each others' courses of action, and to map the difference in the institutional logics actors endorsed. Using entrepreneuring as a method allows me to observe the process through which a social venture is coopted by the logic of its partners and driven to drift away from its original mission.

\section{Findings}

Analysis of empirical material showed a specific tension in the dynamics of social ventures' collaborative work: On the one side, the need for the social venture to collaborate across institutional 
orders to be able to address its social mission; on the other side, the risk of mission-drift that weaker emergent partners run when collaborating with incumbent institutionalised actors. In what follows, the article will focus on the development of a cross-sectoral collaboration by describing two interconnected processes. First, the enactment of a SAF that pivots around a social issue (Selsky and Parker 2005): The process through which actors pertaining to different institutional orders and following distinct institutional logics build collaboration and, through it, set the structure for the emerging SAF. Second, the conflict of logics in the SAF: The extent to which the power differences across partners forces one institutional logic on the whole collaboration, thus setting the weakest partner on a course that drifts it away from its original social mission.

More particular for the case at hand, the collaborating partners in the SAF being developed in Seved came from the institutional orders of 1 . city management; 2 . private property owners; and 3. civil society organizations. The economic dependence of the latter on the first, put them in the weakest position in the emergent SAF, pushing on civil society organisations the concerns for surveillance and violence-containment proper of local city authorities.

\section{Enacting a Strategic Action Field across Institutional Orders}

Research on marginalised and socio-economically vulnerable city suburbs identify four distinct actors in those neighbourhoods:

"the space of the hyperghetto is akin to an entropic and perilous battlefield upon which a four-cornered contest is waged between (i) independent and organized street predators (hustlers and gangs) who seek to plunder what meager riches still circulate in it; (ii) local residents and their grass-roots organisations [...] who strive to preserve the use- and exchange-value of their neighbourhood; (iii) state agencies of surveillance and social control entrusted with containing violence and disorder within the perimeter of the racialized metropolitan core, including social workers, the police, courts, probation and parole agents, etc.; and (iv) outside institutional predators (realtors in particular) for whom converting fringe sections of [the city] for the uses of the middle and upper classes coming back into the city can yield phenomenal profits" (Wacquant 2007:70)

These actors were also visible in Seved, the neighbourhood located on the southern corner of the Sofielund Borough in the City of Malmö, which is, in the case at hand, the geographical area focused by the emergent SAF.

At the time of the study, and along with Rosengård, Holma and Lindängen, Seved was a priority in the city's work to “achieve positive social and economic development, reduce residential segregation, promote socio-economically sustainable living environment and improve school results" (SCB 2015:15). Indeed, unemployment in Seved was well above the national average, social welfare dependency among the highest in Country, and only half of the youth were eligible to attend upper secondary school (ibid.). With $47 \%$ of residents born abroad (ibid.), Seved's socio-economic challenges were often discussed along ethnic lines. Less visible in the statistics though more important for city managers was that organised drug-dealing ruled street life in Seved, with some of the district's teenagers being involved in it. Seved had in fact been central to the increasing defamation in the media of the City of Malmö based on its alleged inability to manage its population of foreign background. Increasing the number of social workers active in the district, setting up a community centre open to all residents, strengthening youth houses as well as other associational initiatives, initiating broad collaborations between the school, museums and other city institutions, and starting summer job 
programs for the youth, everyone with an administrative responsibility in the Sofielund City Borough had been given the mandate to see what they could do to address segregation and socio-economic vulnerability in Seved. In this context, Alexander Miles' (at the time Director of the Sofielund City Borough) eagerness to collaborate with $\mathrm{FiC}$ was not surprising.

In fact, the collaboration of the social venture with the City Borough's Administration proved instrumental in getting access to outdoor walls on which to legally paint the community murals. During the autumn of 2011, I met city administrators and civil servants in Seved; among these, Hugo Frank, "Seved's co-ordinator", the Borough's man in the field or, as they put it, "the spider in the net, that coordinates all activities, networks and actors in Seved" - from social workers, the school, and the police to private property owners, local nonprofits and youth houses. Seeing the potential of having FiC in Seved, Hugo organised a meeting between five property owners, two social workers and me already in October 2011. That is, the institutional sector of City Management quickly mobilised its bureaucratic and social resources and offered them to $\mathrm{FiC}^{3}$ As a result, before the social venture had even opened its doors in the city, and thanks to the mediation of public officials, four property owners were offering their walls for the venture to paint its community murals on, a preliminary timeline had been discussed, and other actors to involve (such as the local school and the local Somali association) were being invited to collaborate. It was the quick accessibility to walls and easiness to build a broad partnership in Seved that decided the neighbourhood $\mathrm{FiC}$ was going to start working with.

The swift mobilisation of various institutional actors to collaborate with when addressing Seved's social challenges showed not only the City's social and bureaucratic resources. It also conjured up the SAF of Seved. A common understanding of the purpose in the field (to achieve positive social and economic development), even if formulated in such vague terms, indicated what actors to invite to the crosssectoral partnership; it pointed to the stakeholders to the social issue that would have an interest in the partnership. That is, the social problem defined in Seved delineated the boundaries of the SAF as it emerged. Yet, as we will see later, the vagueness of the purpose of the incipient collaboration (and SAF) blinded the partners to the different (and potentially conflictive) logics they brought into their work with Seved's specific social challenges.

By March 2012, an agreement was struck between FiC, a private property owner and the City of Malmö. The agreement gave a formal structure to the emergent SAF. LA Properties, who owned several dwellings in Seved, formally agreed to let FiC both outdoor walls to paint on and premises where to open a mural centre. LA Properties had been unable to rent the premises for the previous couple of years and, as the property owner put it when letting them to FiC, "it cannot get worse, it can only get better." The City of Malmö would pay the first six months of rent of the mural centre. In other words, an alliance between the public sector of City administration, the private sector of property owners and the citizen sector was building up in Seved. FiC naively engaged in the triadic partnership, ignorant that stakes and priorities to be satisfied with the collaboration were structured differently in each institutional order:

- City of Malmö's stakes in the SAF emerging around Seved - Often defamed for its organised criminality and high level of unemployment among its population of immigrant background, Rosengård, Holma and Lindängen, as well as Sseved had become central in the City's struggle for

\footnotetext{
3 The speediness with which this meeting was organised points to the need to further investigate the extent to which actors' social skills - a central concept in Fligstein's and McAdam's SAF - hinges on the position actors' occupy in the SAF as well as on the structure of the SAF.
} 
recognition of its city management abilities. For those civil administrators working at the Sofielund City Borough, Seved's development was pegged, to a certain extent, to their own legitimacy in the field of city management. This was particularly exacerbated by the discussions (going on at that moment and made effective as of July 2013) of re-organising the City's administrative boroughs from ten to five. Such a re-organisation would have very direct consequences on Alexander Miles' position as the borough he directed was to be merged with the neighbouring borough. His continuation as a borough director was thus at risk. As he would admit a few months later, on November 2012, "for us, it is a matter of doing things in Seved. I have a strong political pressure put on me." Collaborating with $\mathrm{FiC}$ was thus a means to control drug-dealing and street violence in Seved, to answer to the political struggles within the City of Malmö, and to achieve recognition within the field of city management in Malmö.

- Private property owners's stakes in the SAF emerging around Seved - One of the consequences of street violence had been the property owner's inability to rent out the property located in the derided street corner. Governed by the economic logic that structures the field of property owners, LA Properties saw in FiC a partner in improving the atmosphere in the street and hopefully, at a later stage, facilitating the rental of his premises.

- Citizen sector's stakes in the SAF emerging around Seved - Solving Seved's street violence was far from the objectives of the nonprofit organisations present in Seved (from FiC, to the allotment gardens association or the Somalian association). These organisations' goals were focused in mobilising residents (in general for $\mathrm{FiC}$ and the gardens association, residents with Somali background for the Somalian association), in strengthening the local community. Guided by a community logic, FiC's stakes were committed to raising the voices of the residents and thus representing (in both senses of the term, visualising and acting as spokes-agent) the community.

The table below visualises the partners in the collaboration building up in Seved, their distinct stakes in the emerging SAF, and the institutional logics they brought to the partnership.

\begin{tabular}{|l|l|l|}
\hline \multicolumn{1}{|c|}{$\begin{array}{c}\text { Institutional } \\
\text { order }\end{array}$} & \multicolumn{1}{|c|}{ Interest } & \multicolumn{1}{|c|}{ Logic of the particular field } \\
\hline City Management & Pacify the street. & $\begin{array}{l}\text { City-management logic (top-down approach). } \\
\text { Actors' legitimacy lies in the way Seved is } \\
\text { reported. }\end{array}$ \\
\hline $\begin{array}{l}\text { Local private } \\
\text { business }\end{array}$ & $\begin{array}{l}\text { Rent out their premises (for } \\
\text { which pacification of street } \\
\text { was necessary). }\end{array}$ & Economic logic. \\
\hline $\begin{array}{l}\text { Civil society (FiC } \\
\text { in particular) }\end{array}$ & $\begin{array}{l}\text { Strengthen community. } \\
\text { Raise the voices of residents } \\
\text { in the stigmatised city } \\
\text { suburb. }\end{array}$ & $\begin{array}{l}\text { Community-engagement logic (bottom-up } \\
\text { approach). Actors' legitimacy lies on the extent to } \\
\text { which residents support, and are involved in, civil } \\
\text { associational life in general, and FiC's } \\
\text { community-based mural processes in particular. }\end{array}$ \\
\hline
\end{tabular}

Table 1: Partners in the emerging SAF in Seved 
So far, so good. Either out of a belief in the community-mural methods $\mathrm{FiC}$ was suggesting to introduce in Seved, or out of discouragement and lack of novel suggestions, actors from all three institutional orders agreed on the form of collaboration. They were to introduce community-mural methods to improve the social climate in the neighbourhood.

Although unaware of it at the time, two problems were on sight for the cross-sectoral partnership. One, the collaboration lacked the fourth actor identified by Wacquant (2007) in stigmatised and marginalised city suburbs: "independent and organised street predators." Soon, however, they would make themselves remembered through an increase in street violence. Two, the distinct institutional logics guiding the partners clashed in times of growing neighbourhood tensions. Increased street violence would soon visualise the conflict embedded in the cross-sectoral partnership. In this conflict, the smallest and weakest actor, the nascent social venture, was the easiest to trap into the political struggles of a field that was not its own, leading the organisation to drift away from its original mission.

Initially hopeful by the adamant support from the Administration of the City of Malmö, FiC did not realise that it had been coopted by the institutional logic of City Management into addressing a social problem for which it did not have the resources nor the knowledge and which was beyond its original mission (for two similar cases, see Milbourne and Cushman 2013).

\section{Conflict of logics in the emergent Strategic Action Field}

Indeed, as FiC's team set out to renovate the run-down premises that were to become Frida Kahlo Mural Centre, the organisation became aware of the conflict of logics inherent to the triadic collaboration. In April 2012, FiC's Malmö team realised it was sharing the street corner with an organised drug-dealing gang. It was a core group of six to eight young men that ruled the street and some twenty other that saw up to them. Although most of them lived in Seved, a couple came from the neighbouring boroughs. Several among them had been detained and held under custody for aggressive behaviour, street vandalism, and violent threats, although none had served sentence. The gang quickly presented itself as the fourth actor in the SAF of Seved.

It needs to be mentioned that the young men were the sons, brothers, cousins, friends and neighbours of those FiC wanted to work with, thus residents' ambiguous attitudes towards them. On the one hand, neighbours often complained of having their windows broken, not daring to walk past the street corner, and night's frequent racket and quarrels. Yet, on the other hand, residents in Seved readily defended "our kids for it is society that has never given them any chance." "It's jobs they need, yet nobody ever offers them one. All they do is to send the police to Seved." What's more, at times, residents expressed exasperation with established actors who they saw unwilling to truly solve Seved's conflict. "They would loose their jobs were they to solve Seved's problem."

In mid-May, growing agitation started to become noticeable. In an effort to end drug-dealing in the street, the police, in collaboration with Hugo Frank, had given Daruj's Groceries two months notice to close down the business. The small grocery store was located some 50 meters away from the infamous street corner and much of the drug dealing was carried out in the little shop under the owner's blind eye. According to Hugo and the police, Daruj's closure was connected to the young men's increased anxiety, which was expressed in more threats to neighbours, more stones thrown to residents' windows and more night brawls. A couple of neighbours even reported seeing them in the inner yards making Molotov cocktails. Attacking Frida Kahlo Mural Centre as well was only a matter of time. 
To be sure, one of FiC's team members was verbally abused on May 18 and physically attacked on May 25 when she was closing the Mural Centre for the day. A few days later, on June 11, FiC's Malmö team in its entirety was verbally attacked and physically threatened while they held a meeting inside Frida Kahlo Mural Centre. One of Frida's windows was, for the second time in the last three weeks, broken, fixed on the afternoon that same day, only to be broken again the day after.

Spiralling violence in Seved was not merely the fearful actions of a gang of young men high on drugs. It emerged from the interactions, actions and reactions of actors anchored in various institutional orders, actors' whose approaches to Seved were given by the logic dominant in their respective order. Along with the distinct institutional logics described in the previous section, the partners defined the problem in Seved differently, each definition corresponding to the way in which each institutional order can address the problem so defined and thus gain political acumen in their own orders. Accordingly, city managers saw the problem as one of increased violence, residents as one of lack of jobs, civil society organisations (FiC among them) as one of lack of power.

- Residents - On the one hand, neighbours often complained of having their windows broken, not daring to walk past the street corner, and night's frequent racket and quarrels. Yet, on the other hand, residents in Seved readily defended "their kids" (see quote above). Residents moved Seved's problem from the individual level of criminal activities carried out by a few residents, to the structural level of lack of jobs and (implicitly) ethnic bias of established institutions.

- FiC's original mission was receptive to the alleged bias of the establishment implied in the comments from the residents. Indeed, the very reason to start $\mathrm{FiC}$ was to address residents' frustration about the prevalent image of their suburb and its dwellers of migrant background. This, the biased public debate on those classified as "immigrants", the stigma befallen the areas were they lived, was the core of the challenge the social venture had set out to address. This definition of Seved's social challenge was in line with residents' structural definition of it. The solution FiC suggested was also along collective lines: facilitating community processes that could raise residents' voices, resist dominant stigmatised discussion on Seved, and reformulate the stories about the neighbourhood (see above).

- City administrators - Theirs was an individualist definition of the problem, in which a group of young male residents intimidated all other residents in the neighbourhood. Accordingly, the solutions they offered were all addressed to pacify the area by removing individual felons from the street and by closing down those places where they carried out their criminal activities. It is in this light that one can understand why FiC was offered to open the Mural Centre in the most conflictive corner of the neighbourhood. In a way, FiC was used as a human shield in a combat that was not the one FiC had set out to fight. That is, FiC was coopted for a conflict other than its own. While FiC's mission was to raise the voices of the stigmatised neighbourhood, the social venture had been used as a tool to pacify the neighbourhood.

The management of the incidents of June 2012 by the various actors further evidenced the City of Malmö's stakes in the borough. For instance, the police filed two police reports when only one had been made by one member of the FiC-team. It took a second FiC-member several phone calls and a couple of visits to the police station to take his report (supposedly the second one) down. In a further move, the police tipped Sydsvenskan, the largest daily newspaper in the County, on the happenings of June 11. FiC's Malmö-team suspected that what the police was after was to increase the number of police reports and get media attention in order to increase the budget assigned to them for violence control in Seved. 
The following diagram summarises the stakes the partners in the cross-sectoral collaboration had in Seved:

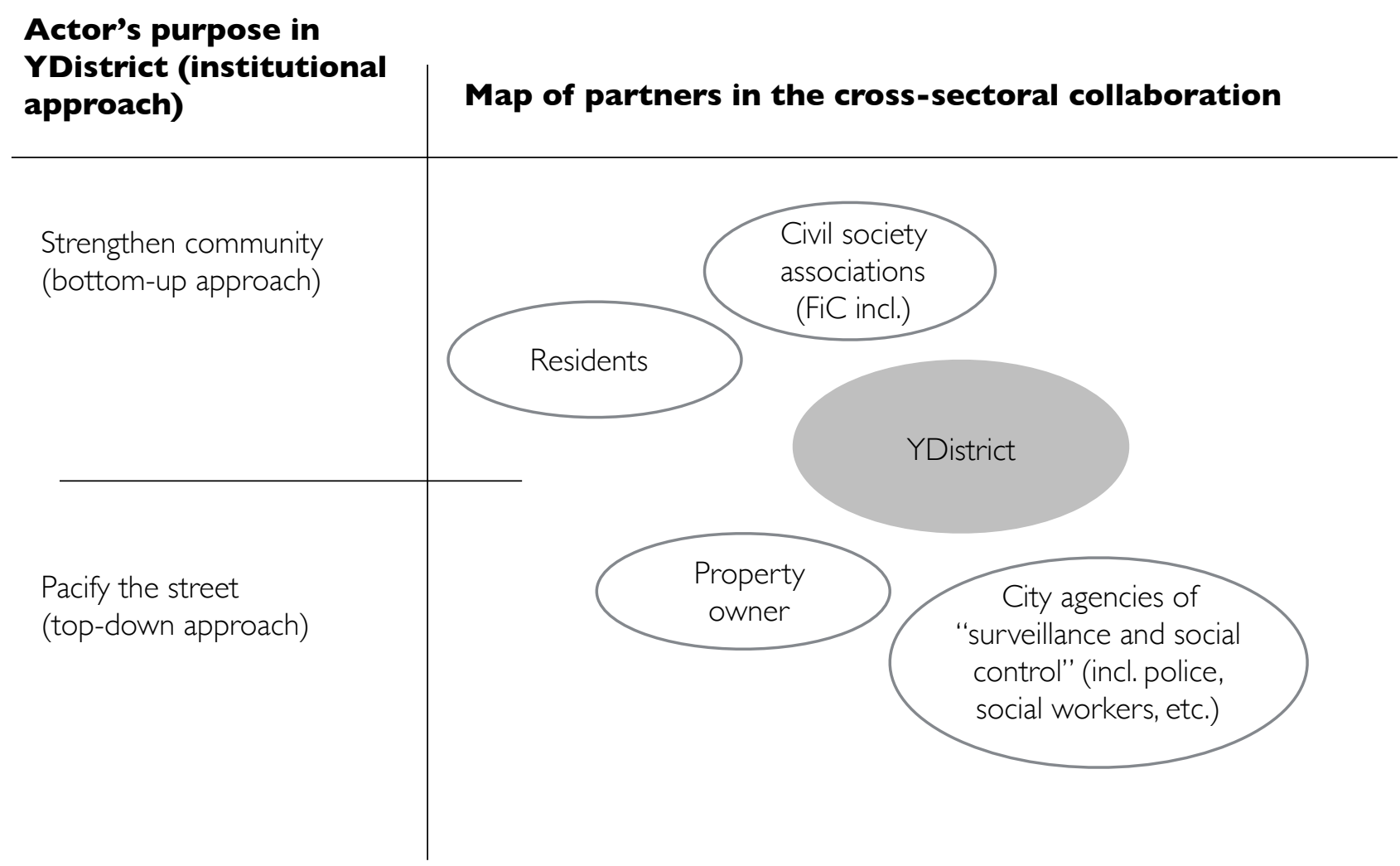

Figure 1: Actors' stakes in Seved

The above diagram represents the actors in the cross-sectoral partnership. Note that the collaboration lacked one of four key actors Wacquant (2007) identifies in stigmatised city suburbs, and around which the SAF revolved: the street gang. Partners' different definitions of the social issue in Seved - in which the street gang was a part - and their different approaches to addressing it, mirror their anchoring in distinct institutional orders. Their stakes in the neighbourhood are given not by Seved's SAF, but by their position in their respective institutional orders: 1 . the organised world of criminality; 2 . citizen sector; 3. city management; 4. private business sector.

Their responses were fashioned along the logics of those institutional orders. And these were not necessarily aligned. Attending to the interests of City management to pacify Seved did not necessarily conduct to the interest of the citizen sector. Indeed, as the article in Sydsvenskan was an example of, FiC was contributing to Seved being further derided in the public debate, contributing to enhance the stigma that the social venture had set out to counter. FiC, that is, had been made captive to the interests of the apparatus within the institutional order of city management.

The problem FiC faced in Seved was thus not only a problem of neighbourhood violence. What at first sight seemed a problem of employees' security due to increased community violence became, at a closer look, a more complex problem of conflict of logics between, on the one side, the institutional order of City Management and to a lesser extent that of real state owners, and, on the other side, the citizen sector at large, spearheaded in this incident by FiC. Embedded in their own institutional orders, 
the firsts had welcomed FiC to serve their interests in the struggles in their own orders. Thus, City managers quickly embraced FiC for what it could contribute to manage and pacify a criminal area. Similarly, property owners appreciated FiC's work to the extent it could ameliorate its economic prospects.

The social venture being the weakest actor in the SAF Seved, dependent on incumbent actors for access to economic and material (walls) resources, was easily recruited to the struggles of the institutional orders on which it depended. As a result, and although FiC-team may have been unaware of it, the social venture was placed at the heart of the work of pacifying the street, something that was away from its original mission and for which it had not the knowledge nor the resources. In this way, the social venture had been coopted by the stronger institutional actors in a struggle that was not its own.

\section{Discussion: Mission-drift in a cross-sectoral partnership}

One of the challenges posed by the research field of social entrepreneurship is to contextualise the forms of collaboration through which social ventures organise for social change. The focus of attention has been predominantly on the individual, hero-like, entrepreneur or on the organisation of the social venture itself (see, for instance Pache and Santos 2013; Bruneel et al. 2016). That is, the focus has been at the micro-level. Yet, if we are to respond to calls to understand social entrepreneurship as a collective endeavour (Montgomery et al. 2012; Dacin et al. 2011), we need to approach the topic from a perspective that allows us to move from the micro- to the meso-level, an approach that allows analysis of the interaction between collaborating partners, an approach, that is, that recognises structure and stability while nonetheless is able to account for agency and change.

In this effort, the article mobilises the theoretical tools handed to us by Fligstein and McAdam in their theory of Strategic Action Fields to analyse the dynamic relationship between partners in a crosssectoral collaboration between a nascent social venture and incumbent institutional actors. In this doing, the unit of analysis is neither the individual social venture nor other individual organisational partners. Rather, focus is on the interaction between the collaborating partners, on the frames and stakes partners bring to the collaboration, and on how these shape both their action in the SAF and the development of the partnership. The article gives an empirical illustration of this dynamic relationship and shows, first, how actors enact a SAF through formalising a collaboration across institutional orders; and second, how the weakest (nascent) actor in the SAF is coopted by incumbent actors into a struggle that pertains to the institutional order that dominates the SAF.

First, empirical material showed the dynamic relationships that constitute a SAF. Acknowledging the need to collaborate across institutional orders if they were to address broad social challenges (such as "achieve positive social and economic development" in a marginalised and stigmatised city suburb), the social venture engaged in a partnership with public and private actors in Seved. It is the social challenge that brought the partners together. That is, it is the social challenge itself that helped demarcate the SAF in Seved. Yet, this very demarcation of the SAF, through a situation that required involvement of three distinct institutional orders - state/public, private and citizen sectors -, with different degrees of power in the SAF, engendered the tensions and conflict of logics that would lead the social venture onto a course it had not set for itself.

It is at this point that the study presented here builds on and further develops research on social entrepreneurship. While such research highlights the embeddedness of social ventures in their social, cultural and institutional contexts (Dacin et al. 2011; Newth and Woods 2014), and calls for studies that 
emphasise the collaborative nature of efforts aimed at social change (Montgomery et al., 2012), it has so far failed to acknowledge the conflictive relationship between social ventures and their partners. In so doing, extant research has also ignored the extent to which such partnerships may lead to the venture drifting away from its original social mission.

This is the second contribution of the article. When discussed in the literature, mission-drift is seen as a result of the conflict between the economic and social logics inherent within the social venture itself (see, for instance, Ebrahim et al. 2014). The case at hand indicates another source of mission-drift: A conflict in the institutional logics that guide the actors a social venture partners with. That is, missiondrift can also be defined as the cooptation of a nascent social venture by the dominant incumbent actors in the SAF in which it acts.

Finally, the developments in the SAF of Seved highlight the need to make an analytical (and conceptual) distinction between SAF and institutional order. That is, while the article's previous two contributions are addressed to the research field of social entrepreneurship, the article's third contribution is to the theory of fields. Fligstein and McAdam write about nested SAFs. This is indeed sometimes the case. The events analysed in this article point to a different structure of SAFs, one where the various fields are not nested into each other but intersect at particular episodes. Hence, the third and final contribution of this article refers to the need to demarcate SAFs along the social issue that brings actors together, along the meta-problem or social challenge around which actors partner and interact (Selsky and Parker 2005). This is to be distinguished from the demarcation of institutional orders along the line of command to which particular actors respond and in which (not through which) they gain (or loose) legitimacy.

Fundamentally, the case presented in this article is not a partnership story. Nor it is a story of scaling up a social venture into a new city. Instead, it is a more complicated account of power dynamics between established state- and emergent non-state-actors. It is a story of the possibility of agency when collaborating with dominant institutional actors. It is a story of the political struggles involved in collaborative efforts aimed at catalysing social change in cities. That is, as others have already warned (Bishop and Waring 2016; ), the case suggests that collaborations between the public sector and the citizen or social sector are potentially volatile hybrids. Yet, as the case suggests, the key to understand change in the face of established institutional orders resides in these volatile collaborations. However, if we are to leverage on the social change potential of such collaborations, partners need to be aware of each others' distinct approaches to the social challenge at hand, as well as be particularly watchful to support the logics and tactics of the weakest one. That is, incumbent institutional actors need to acknowledge (and support) the role of individuals and small organizations in catalysing social change while nonetheless giving stability to the cross-sectoral collaboration.

A final note of practical advice, and to the extent to which such is possible, cross-sectoral collaborations aiming at resolving violence in stigmatised suburbs, should consider engaging into a committed dialogue with those that are seen as the source of violence. In this case, the street gang. They were a key stakeholder in the SAF that defined by the social challenge.

The events described in this article as well as other events that same year led to the social venture deciding to stop its activities in the Malmö in late 2012. The ideas and methods it brought to the city were however taken over by the people and institutions that were involved in the cross-sectoral partnership. To witness, in January 2018, two large murals were inaugurated in the tunnel under the 
road that separates Seved from the rest of the city. School children from the schools FiC had collaborated with participated in the collective process. Further, the artist involved in $\mathrm{FiC}$ has since 2014 conducted several collective murals in collaboration with school children in city districts other than Seved. This raises the question of how to evaluate the impact of a social venture. Most often, impact is assessed on the ground of the venture's direct activities. Yet, as these developments seem to indicate, the new ideas and novel methods a venture one day introduced may impact well beyond the venture's immediate and direct actions.

\section{References}

Austin, J.E., and Seitanidi, M.M. (2012). Collaborative Value Creation: A Review of Partnering Between Nonprofits and Businesses. Part 2: Partnership Processes and Outcomes. Nonprofit and Voluntary Sector Quarterly, 41(6), 929-968.

Austin, J., Stevenson, H., and Wei-Skillern, J. (2006). Social and commercial entrepreneurship: Same, differ- ent, or both? Entrepreneurship Theory and Practice, 30, 1-22.

Aygören, H. (2014). Research in social entrepreneurship: From historical roots to future routes. In P. H. Phan, J. Kickul, S. Bacq, and M. Nordqvist (Eds.), Theory and empirical research in social entrepreneurship. Cheltenham, UK: Edward Elgar.

Bacq, S., and Janssen, F. (2011). The multiple faces of social entrepreneurship: A review of definitional issues based on geographical and thematic criteria. Entrepreneurship \& Regional Development, 23, 373-403.

Barinaga, E. (2017). Tinkering with space: The organizational practices of a nascent social venture." Organization Studies.

Barinaga, E. (2013). Politicising Social Entrepreneurship: Three Social Entrepreneurial Rationalities towards Social Change. Journal of Social Entrepreneurship, 4(3), 347-372.

Barinaga, E. (2012). Overcoming inertia: The social question in social entrepreneurship. In D. Hjorth (Ed.), Handbook on Organizational Entrepreneurship (pp. 242-256): Edward Elgar Publishing.

Battilana, J. Leca, B., and Boxenbaum, E. (2009). How Actors Change Institutions: Towards a Theory of Institutional Entrepreneurship. Academy of Management Annals, 3(1), 65-107.

Benford, R.D., and Snow, D.A. (2000). Framing Processes and Social Movements: An Overview and Assessment. Annual Review of Sociology, 26, 611-639.

Bishop, S., and Waring, J. (2016). Becoming hybrid: The negotiated order on the front line of public-private partnerships. Human Relations, 69(10), 1937-1958.

Brewer, J., and A. Hunter. (1989). Multimethod Research: A Synthesis of Styles. London: Sage. 
Bruneel, J., Moray, N., Stevens, R., and Fassin, Y. (2016). Balancing Competing Logics in ForProfit Social Enterprises: A Need for Hybrid Governance. Journal of Social Entrepreneurship, 7(3), 263-288.

Calas, M.B., Smircich, L., and Bourne, K.A. (2009). Extending the boundaries: Reframing "Entrepreneurship as social change" through feminist perspectives. Academy of Management Review, 34(3), 552-569.

Caroli, M.G., Fracassi, E., Maiolini, R., and Carnini Pulini, S. (2018). Exploring Social Innovation Components and Attributes: A Taxonomy Proposal. Journal of Social Entrepreneurship, 9(2), 94-109.

Cornforth, C. (2014). Understanding and combating mission drift in social enterprises. Social Enterprise Journal, 10(1), 3-20.

Curtis, T. (2008). Finding that grit makes a pearl: A critical re-reading of research into social enterprise. International Journal of Entrepreneurial Behaviour \& Research, 14(5), 276-290.

Dacin, M. T., Dacin, P. A., and Tracey, P. (2011). Social entrepreneurship: A critique and future directions. Organization Science, 22, 1203-1213.

Dacin, P. A., Dacin, M. T., and Matear, M. (2010). Social Entrepreneurship: Why we don't need a new theory and How we move forward from here. Academy of Management Perspectives, 24(3), 37-57.

Daskalaki, M., Hjorth, D., and Mair, J. (2015). Are Entrepreneurship, Communities, and Social Transformation Related? Journal of Management Inquiry, 24(5), 419-423.

Di Domenico, M. L., Haugh, H., and Tracey, P. (2010). Social bricolage: Theorizing social value creation in social enterprises. Entrepreneurship: Theory \& Practice, 34, 681-703.

Douglas, H. (2015). Designing social entrepreneurship education. International Journal of Social Entrepreneurship and Innovation, 3(5), 362-373.

Drayton, W. (2002). The citizen sector: Becoming as entrepreneurial and competitive as business. California Management Review, 44(3), 120-132.

Easter, S., and Dato-On, M.C. (2015). Bridging Ties Across Contexts to Scale Social Value: The Case of a Vietnamese Social Enterprise. Journal of Social Entrepreneurship, 6(3), 320-351.

Ebrahim, A., Battilana, J., and Mair, J. (2014). The Governance of Social Enterprises: Mission Drift and Accountability Challenges in Hybrid Organizations. Research in Organizational Behavior 34:81-100.

Eisenhardt, K. (1989). Building Theories from Case Study Research. Academy of Management Review 14 (4): 532-550. 
Fayolle, A., and Matlay, H. (2009). Social entrepreneurship: a multicultural and multidimensional perspective. In A. Fayolle and H. Matlay (Eds.), Handbook of research on social entrepreneurship (pp. 1-13): Edward Elgar.

Fligstein, N., and McAdam, D. (2012). A Theory of Fields: Oxford University Press.

Fligstein, N. and McAdam, D. (2010). Toward a General Theory of Strategic Action Fields. Sociological Theory, 29(1), 1-26.

Gartner, W.B. (2016). Anecdotes of destiny. In D.B. Audretsch and E.E. Lehmann (Eds.), The Routledge Companion to the Makers of Modern Entrepreneurship (pp.130-145): London / New York: Routledge.

Gartner, W.B. 1989. "Who is an Entrepreneur?" is the Wrong Question. Entrepreneurship: Theory and Practice, Summer, 47-68.

Geertz, C. (2000). Available Light: Anthropological Reflections on Philosophical Topics. Princeton University Press

Gibson-Graham, J. K., and Roelvink, G. (2013). Social innovation for community economies: How action research creates 'other worlds'. In D. MacCallum and F. Moulaert (Eds.), The International Handbook on Social Innovation: Collective Action, Social Learning and Transdisciplinary Research (pp. 454-465): Edward Elgar.

Kickul, J., Griffiths, M.D., and Gundry, L. (2009). Innovating for Social Impact: Is Bricolage the Catalyst for Change? In A. Fayolle and H. Matlay (Eds.), Handbook of research on social entrepreneurship (pp. 232-251): Edward Elgar.

Henry, C. (2015). Doing Well by Doing Good: Opportunity Recognition and the Social Enterprise Partnership. Journal of Social Entrepreneurship, 6(2), 137-160.

Johannisson, B. (2011). Towards a practice theory of entrepreneuring. Small Business Economics, $36(2), 135-50$.

Johansson, H., Arvidsson, M., and Johansson, S. (2015). Welfare Mix as a Contested Terrain: Political Positions on Government-Non-profit Relations at National and Local Levels in a Social Democratic Welfare State. Voluntas: International Journal of Voluntary and Nonprofit Organizations, 26(5), 1601-1619.

Kalantaridis, C. (2014). Institutional change in the Schumpeterian-Baumolian construct: power, contestability and evolving entrepreneurial interests. Entrepreneurship \& Regional Development: An International Journal, 26(1-2), 1-22.

Light, P. (2009). Social entrepreneurship revisited. Stanford Social Innovation Review, 7(3), 21-22.

Mair, J., Mayer, J., and Lutz, E. (2015). Navigating Institutional Plurality: Organizational Governance in Hybrid Organizations. Organization Studies, 36(6), 713-739. 
Mair, J., and Martí, I. (2006). Social entrepreneurship research: A source of explanation, prediction, and delight. Journal of World Business, 41, 36-44.

Milbourne, L., and Cushman; M. (2013). From the Third Sector to the Big Society: How Changing UK Government Policies Have Eroded Third Sector Trust. Voluntas:International Journal of Voluntary and Nonprofit Organizations, 24, 485-508.

Milbourne, L., and Murray, U. (2011). Negotiating Interactions in State-Voluntary Sector Relationships: Competitive and Collaborative Agency in an Experiential Workshop. Voluntas:International Journal of Voluntary and Nonprofit Organizations, 22, 70-92.

Montgomery, A. W., Dacin, P. A., and Dacin, M. T. (2012). Collective Social Entrepreneurship: Collaboratively Shaping Social Good. Journal of Business Ethics, 111, 375-388.

Nemec, J., Klimovský, D., Meričková, B. and Svidroňová, M. (2017). Co-Creation as a Social Innovation in Delivery of Public Services at Local Government Level. In E. Schoburgh and R. Ryan (Eds.), Handbook of Research on Sub-National Governance and Development (pp. 281-303): IGI Global.

Newth, J., and Woods, C. (2014). Resistance to Social Entrepreneurship: How Context Shapes Innovation. Journal of Social Entrepreneurship, 5(2), 192-213.

Nicholls, A. (2008). Social Entrepreneurship: New Models of Sustainable Social Change. Oxford: Oxford University Press.

Pache, A.C., and Santos, F. (2013). Inside the Hybrid Organization: Selective Coupling as a Response to Competing Institutional Logics. Academy of Management Journal, 56(4), 972-1001.

Palmås, K. (2012). Re-assessing Schumpeterian assumptions regarding entrepreneurship and the social. Social Enterprise Journal, 8(2), 141-155.

Polkinghorne, D. 1983. Methodology for the Human Sciences. Albany, NY: State University of New York Press.

Quinn, J.B. 1980. Strategies for Change: Logical Incrementalism. Homewood, IL: Dow-Jones Irwin

Reay, T., and Hining, C. R. B. (2009). Managing the Rivalry of Competing Institutional Logics. Organization Studies, 30(6), 629-652.

Sarasvathy, S.D., and Venkataraman, S. (2011). Entrepreneurship as Method: Open Questions for an Entrepreneurial Future. Entrepreneurship: Theory \& Practice, 35(1), 113-135.

SCB (Statistiska Centralbyrån). (2015). Integration - med fokus på 15 stadsdelar. Örebro: SCBTryck. 
Seelos, C., Mair, J., Battilana, J., and Dacin, M. T. (2011). The embeddedness of social entrepreneurship: Understanding variation across local communities. Research in the Sociology of Organizations, 33, 333-363.

Selsky, J. W., and Parker, B. (2005). Cross-Sector Partnerships to Address Social Issues: Challenges to theory and practice. Journal of Management, 31(6), 849-873.

Smith, B. R., and Stevens, C. E. (2010). Different types of social entrepreneurship: The role of geography and embeddedness on the measurement and scaling of social value.

Entrepreneurship \& Regional Development, 22(6), 575-598.

Steyaert, C. (2011). Entrepreneurship as in(ter)vention: Reconsidering the conceptual politics of method in entrepreneurship studies. Entrepreneurship \& Regional Development: An International Journal, 23, 77-88.

Sonnino, R., and Griggs-Trevarthen, C. (2013). A resilient social economy? Insights from the community food sector in the UK. Entrepreneurship \& Regional Development: An International Journal, 25, 272-292.

Sud, M., VanSandt, C. V., and Baugous., A. M. (2009). Social Entrepreneurship: The Role of Institutions. Journal of Business Ethics, 85, 201-216.

Swedberg, R. (2006). Social entrepreneurship: the view of the young Schumpeter. In C. Steyaert and D. Hjorth (Eds.), Entrepreneurship as Social Change (pp. 21-34): Edward Elgar.

Swedberg, R. (2009). Schumpeter's full model of entrepreneurship: economic, non-economic and social entrepreneurship. In R. Ziegler (Ed.), An Introduction to Social Entrepreneurship: Voices, Preconditions, Contexts (pp.77-106): Edward Elgar.

Tapsell, P., and Woods, C. (2010). Social entrepreneurship and innovation: Self-organization in an indigenous context. Entrepreneurship \& Regional Development, 22(6), 535 - 556.

Spradley, J.P. (1980). Participant Observation. Orlando, Florida: Harcourt College Publishers

Tracey, P., Phillips, N. and Jarvis, O. (2011). Bridging institutional entrepreneurship and the creation of new organizational forms: a multilevel model. Organization Science, 22, 60-80.

Townsend, D. M., and Hart, T. A. (2008). Perceived institutional ambiguity and the choice of organizational form in social entrepreneurial ventures. Entrepreneurship Theory Practice, 32, $685-700$.

Trivedi, C., and Stokols, D. (2011). Social enterprises and commercial enterprises: Fundamental differences and defining features. Journal of Entrepreneurship, 20(1), 1-32.

Van de Ven, A.H. (2007). Engaged Scholarship: A guide for organizational and social research. Oxford University Press. 
Vermeulen, F., Minkoff, D. C., and Meer, T.v.d. (2016). The Local Embedding of CommunityBased Organizations. Nonprofit and Voluntary Sector Quarterly, 45(1), 23-44.

Voorberg, W.H., Beckers, V.J.J.M. \& Tummers, L.G. (2015). A Systematic Review of Co-Creation and Co-Production: Embarking on the social innovation journey. Public Management Review, 17(9), 1333-1357.

Wacquant, L. (2007). Territorial stigmatization in the age of advanced marginality. Thesis Eleven, 91, 66-77. 